\title{
Effect of Supplementing Plant Derived 1, 25 Dihydroxy Cholecalciferol on Performance and Bone Mineralization in Broiler Chicken Fed Suboptimal Concentrations of Calcium and Non Phytate Phosphorus
}

\author{
Narwade Vishal Shesherao, D. Nagalakshmi*, S.V. Rama Rao, \\ N. Nalini Kumari, T. Raghunanadan and K. Sridhar \\ Department of Animal Nutrition, College of Veterinary Science, \\ Rajendranagar, Hyderabad-30, India \\ *Corresponding author
}

\author{
A B S T R A C T
}

An experiment was conducted on 250 day old broiler chicks to investigate the effect of replacing cholecalciferol (CC) (1800 ICU/kg diet) (diet 1) with plant derived 1, $25(\mathrm{OH})_{2}$

\begin{tabular}{|l|}
\hline Ke y w o r d s \\
Broiler \\
chicken, \\
Calcium, \\
Cholecalciferol, \\
Phosphorus, \\
Plant derived. \\
\hline Article Info \\
\hline $\begin{array}{l}\text { Accepted: } \\
\text { 19 June 2017 } \\
\text { Available Online: } \\
\text { 10 July } 2017\end{array}$ \\
\hline
\end{tabular}
$\mathrm{D}_{3}$, (PD metabolite) at 25, 50, 75 and $100 \%$ (diet 2 to 5, respectively) on performance, bone mineralization and Calcium $(\mathrm{Ca})$ and Phosphorus $(\mathrm{P})$ retention in broiler chicken $(0$ to $42 \mathrm{~d}$ of age) fed diets containing suboptimal levels of $\mathrm{Ca}$ and non phytate $\mathrm{P}$ (NPP) (0.7\% $\mathrm{Ca}$ and $0.35 \%$ NPP during starter and $0.7 \% \mathrm{Ca}$ and $0.35 \%$ NPP during finisher). The chicks were randomly allotted to 50 replicates, which were in turn allotted to above 5 diets. Each diet was offered ad libitum and all birds were reared under uniform conditions. During starter, finisher phases and for all overall period body weight gains, feed intake and feed conversion ratio were comparable among the all dietary treatments. Serum $\mathrm{Ca}$ and inorganic P levels estimated from blood collected on $35^{\text {th }} \mathrm{d}$ were comparable among the treatments. Bone weight, strength, ash percentage, $\mathrm{Ca}$ and $\mathrm{P}$ contents in bone ash were significantly $(\mathrm{P}<0.05)$ improved by replacing synthetic $\mathrm{CC}$ with $\mathrm{PD}$ metabolite but level of replacement $(25,50,75$ or $100 \%)$ had no significant effect. Similarly, P retention improved $(\mathrm{P}<0.05)$ with dietary incorporation of $\mathrm{PD}$ metabolite but was independent to level of replacement, while Ca retention was comparable among the dietary treatments. The results of the study indicated that supplementing plant derived $1,25(\mathrm{OH})_{2} \mathrm{D}_{3}(45,90$, 135 or $180 \mathrm{ICU} / \mathrm{kg}$ ) significantly improved bone weight, strength, ash percentage, $\mathrm{Ca}$ and $\mathrm{P}$ contents in broiler chicken fed on suboptimal levels of Ca and NPP.

\section{Introduction}

Broiler chicken has been genetically improved to attain maximum weight in short duration, predisposing the birds to leg disorders and locomotion problem due to higher body mass and skeletal weight ratio (Ref). These problems in a way reduce farmers profit not only by affecting birds' performance but also by increasing the carcass condemnation in slaughter house.
Vitamin $D_{3}$ is important for maintenance of skeletal health due to its involvement in calcium $(\mathrm{Ca})$ and phosphorus $(\mathrm{P})$ metabolism. Commercially higher concentration of vitamin $\mathrm{D}_{3}$ (cholecalciferol; $\mathrm{CC}$ ) is added in broiler diets to prevent skeletal disorders. Several researchers suggested that dietary supplementation with high levels of $\mathrm{CC}$ to diet with suboptimal $\mathrm{Ca}$ and $\mathrm{P}$ could reduce 
the incidences and severity of tibial dyschondroplasia and skeletal disorders in broilers (Driver et al., 2006; Rama Rao et al., 2006). Also, the suboptimal concentration of these minerals enhances the utilization of phytic phosphorus (PP) utilization in chicken (Biehl and Baker, 1997; Applegate et al., 2003).

Physiologically vitamin $\mathrm{D}_{3}$ metabolites (25 $\left.(\mathrm{OH}) \mathrm{D}_{3} ; 1(\mathrm{OH}) \mathrm{D}_{3} ; 1,25(\mathrm{OH})_{2} \mathrm{D}_{3}\right)$ are more effective than cholecalciferol because the efficiency of conversion of cholecalciferol to active metabolites $\left[25(\mathrm{OH}) \mathrm{D}_{3}\right.$ in liver and $1,25(\mathrm{OH})_{2} \mathrm{D}_{3}$ in kidney] in biological system is not $100 \%$ (Yan and Waldroup, 2006; Goodgame et al., 2011). Active metabolites may directly reach the target tissue by bypassing the hydroxylation steps in liver and kidney, hence exerts more potency than vitamin $\mathrm{D}_{3}$ (Goodgame et al., 2011).

Studies have indicated that $25(\mathrm{OH}) \mathrm{D}_{3}$ and 1 , $25(\mathrm{OH})_{2} \quad \mathrm{D}_{3}$ were superior to cholecalciferol as source of vitamin $\mathrm{D}$ in improving $\mathrm{Ca}$ and $\mathrm{P}$ utilization and tibial strength (Papesova et al., 2008; Michalczuk et al., 2010; Goodgame et al., 2011). Even though the concept is well established, it is not penetrated to field level due to high cost of synthetic metabolites compared to vitamin $\mathrm{D}_{3}$. Certain plants like Solanum glaucophyllum and Cestrum dirunum contains appreciable amounts of $\mathrm{D}_{3}$ metabolites and could be used as source of vitamin $\mathrm{D}_{3}$ and these plant derived compounds are less expensive than synthetic vitamin $\mathrm{D}_{3}$ metabolite.

Moreover, the vitamin $\mathrm{D}_{3}$ activity in $\mathrm{PD}$ metabolite was considered 10 times potent than CC (DeLuca, 1974). Thus, the present study was carried out to investigate the effect of supplementing plant derived vitamin $\mathrm{D}_{3}$ metabolites at graded concentration in diet containing suboptimal levels of $\mathrm{Ca}$ and NPP on performance and bone mineralization in commercial broiler chicken.

\section{Materials and Methods}

The plant derived 1,25 $(\mathrm{OH})_{2} \quad \mathrm{D}_{3} \quad(\mathrm{PD}$ metabolite) and synthetic cholecalciferol (CC) used in the present investigation was procured from Indian Herbs Specialties Private Limited (India) and DSM India private Limited, respectively. Two hundred and fifty, day old commercial broiler male chicks were randomly allotted to 50 replicates with 5 chicks in each and reared under uniform management conditions from day one through $42 \mathrm{~d}$ of age. The replicates were randomly allotted to 5 treatments with 10 replicates in each. All replicates were housed in electrically heated battery cages having raised wire floors and fitted with feeder, water and a droppings tray underneath. Birds were immunized for Newcastle disease at $7^{\text {th }}$ and $21^{\text {st }}$ day of age with Lasota vaccine and infectious bursal disease at $14^{\text {th }}$ day of age with Georgia strain vaccine. All replicates were offered the respective diets ad libitum and with clean and fresh drinking water.

A corn-soybean meal based basal diet (BD) was prepared for starter and finisher phases to meet the nutritional requirements (NRC, 1994) for commercial broiler chicken, except $\mathrm{Ca}$ and NPP which were kept at suboptimal levels i.e., $0.7 \% \mathrm{Ca}$ and $0.35 \% \mathrm{NPP}$ during starter and $0.5 \% \mathrm{Ca}$ and $0.25 \% \mathrm{NPP}$ during finisher phase (Table 1). The control group was BD supplemented with (synthetic source, $1800 \mathrm{ICU} / \mathrm{kg}$ ) and in experimental diets the synthetic CC and plant derived 1, $25(\mathrm{OH})_{2} \mathrm{D}_{3}$ were in ratio of 75:25 (1200:45 ICU/kg diet), 50:50 (900:90 ICU/kg diet), 25:75 (450:135 ICU/kg diet) and 0:100\% (0:180 ICU/kg diet) i.e., plant derived $1,25(\mathrm{OH})_{2} \mathrm{D}_{3}$ was replacing cholecalciferol at 25, 50 and $75 \%$ respectively. The appropriate quantity of plant derived vitamin $\mathrm{D}_{3}$ metabolite was added considering its $\mathrm{D}_{3}$ activity to be 10 times potent than cholecalciferol. 
The body weight and feed intake of each bird was recorded at weekly intervals to arrive at the weight gain, feed intake and feed conversion ratio (FCR) (feed intake/ weight gain). On $35^{\text {th }}$ day, blood samples were collected from one bird per replicate and serum was separated and stored at $-20^{\circ} \mathrm{C}$ for estimation of $\mathrm{Ca}$ (Gitelman, 1967) and $\mathrm{P}$ (Fiske and Subbarow, 1925). At 42 days of age, 1 bird from each replicate was randomly selected and slaughtered by cervical dislocation. Both the tibiae were freed from soft tissue. The dried $\left(100^{\circ} \mathrm{C} / 3 \mathrm{~h}\right)$ bone samples were defattened by extracting with petroleum ether for $48 \mathrm{~h}$ and its weight was measured. The breaking strength of the bone was measured using Universal testing machine (Kalpak Tech services) with $5 \mathrm{~cm}$ gauge length and $5 \mathrm{~cm} / \mathrm{min}$ load cell speed. After estimating the bone strength, both tibiae of each bird were ashed together $\left(600 \pm 20^{\circ} \mathrm{C} / 6\right.$ h) in a microwave muffle furnace (BR, 6000521, Phoenix) to estimate the bone ash content and then mineral extract was prepared to determine the $\mathrm{Ca}$ (Atomic Absorption Spectrophotometer, Elmer Analyst 100) and P (Fiske and Subbarow, 1925) concentrations in bone ash.

After growth trial (42 d), 3 days metabolic trial involving total feces collection was conducted on one bird per replicate to determine the $\mathrm{Ca}$ and $\mathrm{P}$ retention. During metabolic trial, daily feed intake and faeces voided was recorded. Representative samples of feed offered, residue left and total faeces voided were analyzed for dry matter, $\mathrm{Ca}$ (AOAC, 2012) and total $\mathrm{P}$ concentrations (Fiske and Subbarow, 1925).

The data was subjected to one way analysis of variance (Snedecor and Cochran, 1994). The differences between the means were compared using Duncan's multiple range test (Duncan, 1955).

\section{Results and Discussion}

\section{Growth performance}

Dietary replacement of vitamin $D_{3}$ supplementation from synthetic source to plant derived $1,25(\mathrm{OH})_{2} \mathrm{D}_{3}$ at $25,50,75$ or $100 \%$ level had no influence on body weight gain, feed intake and feed conversion ratio (FCR) and they were comparable with control group (vitamin $\mathrm{D}_{3}$ solely from synthetic source) (Table 1). The lack of response among the birds on performance due to dietary replacement of synthetic $\mathrm{CC}$ with plant derived active $1,25(\mathrm{OH})_{2} \mathrm{D}_{3}$ (PD metabolite) might be due to the adequacy of $\mathrm{Ca}$ and NPP levels present in the BD and also due to the fact that the level of $\mathrm{CC}$ in the BD (1800 ICU/kg diet) might have supported the birds growth. Rama Rao et al., (2006) observed no significant difference in broilers performance (weight gain and FCR) supplemented with suboptimal levels of $\mathrm{Ca}$ and $\mathrm{P}$ (0.5 and $0.25 \%$, respectively) along with either 2400 or 3600 ICU CC/kg diet. Similarly, Garcia et al., (2013) $\left[25(\mathrm{OH}) \mathrm{D}_{3}\right.$ and $1,25(\mathrm{OH})_{2} \mathrm{D}_{3}$ ] and Landy et al., (2014) $\left[\begin{array}{ll}1 \alpha(\mathrm{OH}) & \mathrm{D}_{3}\end{array}\right]$ observed no significant difference in broiler performance with dietary replacement of vitamin $D_{3}$ with their active metabolites.

\section{Bone variables, serum $\mathrm{Ca}$ and $\mathrm{P}$ concentrations and $\mathrm{Ca}$ and $\mathrm{P}$ retention}

Bone strength, ash percentage and $\mathrm{Ca}$ content in bone ash significantly $(\mathrm{P}<0.05)$ improved with replacement of $\mathrm{CC}$ with $\mathrm{PD}$ metabolite (Table 2) but level of replacement $(25,50,75$ or $100 \%$ ) had no influence on these parameters. Bone weight significantly $(\mathrm{P}<0.05)$ improved with replacement of $\mathrm{CC}$ at 25,50 and $75 \%$ with PD metabolite compared to control $(100 \% \quad \mathrm{CC})$ while at $100 \%$ replacement, bone weight was statistically comparable with control and other dietary treatments (Table 2). 
Int.J.Curr.Microbiol.App.Sci (2017) 6(7): 1634-1641

Table.1 Effect of supplementing plant derived 1, 25 dihydroxy cholecalciferol on performance of broilers (0-6 weeks)

\begin{tabular}{|c|c|c|c|c|c|c|c|c|c|}
\hline \multirow{2}{*}{ Diet } & \multicolumn{3}{|c|}{ Body weight gain (g) } & \multicolumn{3}{|c|}{ Feed intake (g) } & \multicolumn{3}{|c|}{$\begin{array}{l}\text { Feed conversion ratio } \\
\text { (g intake/g gain) }\end{array}$} \\
\hline & $\begin{array}{c}\text { Starter } \\
(0-3 w k)\end{array}$ & $\begin{array}{l}\text { Finisher } \\
(4-6 w k)\end{array}$ & $\begin{array}{c}\text { Total } \\
(0-6 \mathrm{wk})\end{array}$ & $\begin{array}{l}\text { Starter } \\
(0-3 w k)\end{array}$ & $\begin{array}{l}\text { Finisher } \\
(4-6 w k)\end{array}$ & $\begin{array}{c}\text { Total } \\
(0-6 w k)\end{array}$ & $\begin{array}{c}\text { Starter } \\
(0-3 w k)\end{array}$ & $\begin{array}{l}\text { Finisher } \\
(4-6 w k)\end{array}$ & $\begin{array}{c}\text { Total } \\
(0-6 \text { wk) }\end{array}$ \\
\hline $\mathrm{BD}+100 \% \mathrm{CC}$ (control) & 743.6 & 1516 & 2260 & 949.1 & 2678 & 3628 & 1.28 & 1.77 & 1.60 \\
\hline $\mathrm{BD}+75 \% \mathrm{CC}+25 \% \mathrm{PD}-1,25(\mathrm{OH})_{2} \mathrm{D}_{3}$ & 721.0 & 1494 & 2215 & 909.4 & 2593 & 3503 & 1.26 & 1.74 & 1.58 \\
\hline $\mathrm{BD}+50 \% \mathrm{CC}+50 \% \mathrm{PD}-1,25(\mathrm{OH})_{2} \mathrm{D}_{3}$ & 719.8 & 1524 & 2243 & 913.9 & 2766 & 3680 & 1.27 & 1.82 & 1.64 \\
\hline $\mathrm{BD}+25 \% \mathrm{CC}+75 \% \mathrm{PD}-1,25(\mathrm{OH})_{2} \mathrm{D}_{3}$ & 748.2 & 1514 & 2263 & 947.6 & 2777 & 3725 & 1.27 & 1.83 & 1.65 \\
\hline $\mathrm{BD}+100 \% \mathrm{PD}-1,25(\mathrm{OH})_{2} \mathrm{D}_{3}$ & 743.0 & 1535 & 2278 & 944.6 & 2786 & 3731 & 1.27 & 1.82 & 1.64 \\
\hline SEM & 7.39 & 12.40 & 16.20 & 8.65 & 30.30 & 35.44 & 0.006 & 0.015 & 0.012 \\
\hline $\mathrm{N}$ & 10 & 10 & 10 & 10 & 10 & 10 & 10 & 10 & 10 \\
\hline $\mathrm{P}$ value & 0.624 & 0.890 & 0.792 & 0.404 & 0.199 & 0.232 & 0.965 & 0.215 & 0.224 \\
\hline
\end{tabular}

Each pen is a replicate of 5 chicks, SEM: Standard Error Mean

$\mathrm{CC}$ : Synthetic cholecalciferol, PD-1,25(OH) $)_{2} \mathrm{D}_{3}$ - Plant derived $1,25(\mathrm{OH})_{2} \mathrm{D}_{3}$ 
Table.2 Effect of supplementing plant derived 1,25 dihydroxy cholecalciferol on serum $\mathrm{Ca}$ and $\mathrm{P}$ contents, bone variables and $\mathrm{Ca}$ and $\mathrm{P}$ retention in broilers

\begin{tabular}{|c|c|c|c|c|c|c|c|c|c|}
\hline \multirow[b]{2}{*}{ Diet } & \multicolumn{2}{|c|}{ Serum } & \multicolumn{5}{|c|}{ Bone variables } & \multicolumn{2}{|c|}{ Retention } \\
\hline & $\begin{array}{c}\mathrm{Ca} \\
(\mathrm{mg} / \mathrm{dl})\end{array}$ & $\begin{array}{c}\mathrm{P} \\
(\mathrm{mg} / \mathrm{dl})\end{array}$ & $\begin{array}{l}\text { Weight } \\
\text { (g) }\end{array}$ & $\begin{array}{l}\text { Strength } \\
\text { (N) }\end{array}$ & $\begin{array}{l}\text { Ash } \\
(\%)\end{array}$ & $\begin{array}{l}\mathrm{Ca} \\
(\%)\end{array}$ & $\begin{array}{l}\mathrm{P} \\
(\%)\end{array}$ & $\begin{array}{l}\mathrm{Ca} \\
(\%)\end{array}$ & $\begin{array}{l}\mathrm{P} \\
(\%)\end{array}$ \\
\hline $\mathrm{BD}+100 \% \mathrm{CC}$ (control) & 9.29 & 4.41 & $4.77^{\mathrm{b}}$ & $49.54^{\mathrm{b}}$ & $47.75^{\mathrm{b}}$ & $33.70^{\mathrm{b}}$ & $16.75^{\mathrm{b}}$ & 54.51 & $42.84^{\mathrm{b}}$ \\
\hline $\mathrm{BD}+75 \% \mathrm{CC}+25 \% \mathrm{PD}-1,25(\mathrm{OH})_{2} \mathrm{D}_{3}$ & 9.65 & 4.62 & $5.65^{\mathrm{a}}$ & $65.14^{\mathrm{a}}$ & $52.56^{\mathrm{a}}$ & $36.60^{\mathrm{a}}$ & $18.29^{\mathrm{a}}$ & 54.51 & $47.96^{\mathrm{a}}$ \\
\hline $\mathrm{BD}+50 \% \mathrm{CC}+50 \% \mathrm{PD}-1,25(\mathrm{OH})_{2} \mathrm{D}_{3}$ & 9.48 & 4.73 & $5.68^{\mathrm{a}}$ & $67.46^{\mathrm{a}}$ & $50.34^{\mathrm{a}}$ & $36.20^{\mathrm{a}}$ & $17.50^{\mathrm{ab}}$ & 53.46 & $46.76^{\mathrm{a}}$ \\
\hline $\mathrm{BD}+25 \% \mathrm{CC}+75 \% \mathrm{PD}-1,25(\mathrm{OH})_{2} \mathrm{D}_{3}$ & 9.78 & 4.71 & $5.73^{\mathrm{a}}$ & $69.24^{\mathrm{a}}$ & $51.34^{\mathrm{a}}$ & $36.50^{\mathrm{a}}$ & $18.35^{\mathrm{a}}$ & 55.87 & $48.75^{\mathrm{a}}$ \\
\hline $\mathrm{BD}+100 \% \mathrm{PD}-1,25(\mathrm{OH})_{2} \mathrm{D}_{3}$ & 9.53 & 4.27 & $5.34^{\mathrm{ab}}$ & $63.67^{\mathrm{a}}$ & $50.80^{\mathrm{a}}$ & $36.05^{\mathrm{a}}$ & $17.62^{\mathrm{ab}}$ & 54.57 & $48.75^{\mathrm{a}}$ \\
\hline SEM & 0.42 & 0.12 & 0.12 & 2.22 & 0.42 & 0.29 & 0.15 & 0.47 & 0.54 \\
\hline $\mathrm{N}$ & 10 & 10 & 10 & 10 & 10 & 10 & 10 & 10 & 10 \\
\hline$P$ value & 0.930 & 0.723 & 0.053 & 0.033 & 0.003 & 0.004 & 0.001 & 0.638 & 0.001 \\
\hline
\end{tabular}

Each pen is a replicate of 5 chicks, SEM: Standard Error Mean

${ }^{\mathrm{ab}}$ Means with different superscript in a row differ significantly: $\mathrm{P}<0.05, \mathrm{P}<0.01$

$\mathrm{CC}$ : Synthetic cholecalciferol, PD-1,25(OH $)_{2} \mathrm{D}_{3}$ : Plant derived $1,25(\mathrm{OH})_{2} \mathrm{D}_{3}$ 
Similarly, $\mathrm{P}$ content in bone ash improved with replacement of $\mathrm{CC}$ with PD metabolite but significant improvement was observed at 25 and $75 \%$ replacement (Table 2). Replacing $\mathrm{CC}$ with PD metabolite enhanced retention of $\mathrm{P}$, but the improvement $(\mathrm{P}<0.05)$ was independent of level of inclusion. The $\mathrm{Ca}$ and $\mathrm{P}$ concentrations in serum and $\mathrm{Ca}$ retention were comparable among the dietary treatments (Table 2).

Rama Rao et al., (2006) predicted the requirement of $\mathrm{CC}$ for maximum tibia ash as $3485 \mathrm{ICU} / \mathrm{kg}$, which was higher than the requirement predicted for weight gain and FCR (3182 ICU/kg) in chicks fed diets containing suboptimal levels of $\mathrm{Ca}$ and $\mathrm{P}$ (0.5\% Ca and $0.25 \%$ NPP). Similarly, Sun et al., (2013) observed increased tibial ash percentage and strength in broiler with vitamin $\mathrm{D}_{3}$ supplementation in dose dependent manner (200, 2000 and 4000 ICU/kg). Rama Rao et al., (2007a and b) noticed increase $(\mathrm{P}<0.05)$ in tibial ash content with increase in the levels of CC from 200 to $3600 \mathrm{ICU} / \mathrm{kg}$ in broiler diet. Similarly, in the present study, dietary replacement of synthetic CC with PD metabolite significantly $(\mathrm{P}<0.05)$ increased bone ash, calcium and phosphorus content (Table 2). This could be due to higher bioavailability of $1,25(\mathrm{OH})_{2} \mathrm{D}_{3}$ compared to synthetic $\mathrm{CC}$, as $\mathrm{CC}$ has to be converted into biological active form $(1,25$ $\left.(\mathrm{OH})_{2} \mathrm{D}_{3}\right)$ in the body to produce action and this conversion in not $100 \%$ in biological system (Goodgame et al., 2011). In concurrence to our results, Papesova et al., (2008) observed significant $\quad(\mathrm{P}<0.05)$ improvement in bone $\mathrm{Ca}$ and $\mathrm{P}$ contents in bone with partial replacement of vitamin $\mathrm{D}_{3}$ with $25(\mathrm{OH}) \mathrm{D}_{3}$ in broilers. Similarly, Gómez-Verduzco et al., (2013) observed improvement $(\mathrm{P}<0.05)$ in bone calcification of broiler chicken with supplementation of vitamin $\mathrm{D}_{3}$ in combination of $\mathrm{CC}$ and 25 $(\mathrm{OH}) \mathrm{D}_{3}$. Supplementation of $0.25 \%$ Cestrum dirunum (Chennaiah et al., 2007), $10 \mu \mathrm{g} / \mathrm{kg}$ of Solanum glaucophyllum (Bachmann et al., 2013) or $5 \mu \mathrm{g} / \mathrm{kg}$ Solanum glaucophyllum (Cheng et al., 2004) improved the bone variables in broilers compared to basal or control diet.

The $\mathrm{P}$ retention improved $(\mathrm{P}<0.05)$ with dietary substitution of synthetic $\mathrm{CC}$ with $\mathrm{PD}$ metabolites, irrespective of level of inclusion. The enhanced $\mathrm{P}$ utilization with $\mathrm{PD} 1,25$ $(\mathrm{OH})_{2} \mathrm{D}_{3}$ could be the effective stimulation of intestinal phytase activity (Hardy and Edwards, 1993; Applegate et al., 2003) and its deposition in bones (Table 2). Similarly, Edwards (2002) observed significant $(\mathrm{P}<0.01)$ improvement in $\mathrm{P}$ retention in broiler chicken with $1, \quad 25 \quad(\mathrm{OH})_{2} \quad \mathrm{D}_{3}$ supplementation compared to addition of CC. Increased $(\mathrm{P}<0.05) \quad \mathrm{Ca}$ and $\mathrm{P}$ levels in the bone (mineralization), consequently increased $(\mathrm{P}<0.05)$ the bone weight and strength with substitution of $\mathrm{CC}$ with plant derived 1, 25 $(\mathrm{OH})_{2} \quad \mathrm{D}_{3}$ with no effect of level of replacement.

The results of the study indicated that supplementing plant derived $1,25(\mathrm{OH})_{2} \mathrm{D}_{3}$ as source of vitamin $\mathrm{D}_{3}$ replacing synthetic $\mathrm{CC}$ to diets with suboptimal levels of $\mathrm{Ca}$ and NPP improved bone weight, strength, ash, Ca and $\mathrm{P}$ contents in bone ash, with no effect on performance in broilers, but replacing $\mathrm{CC}$ beyond $25 \%$ by PD $1,25(\mathrm{OH})_{2} \mathrm{D}_{3}$ had no further improvement.

\section{References}

Applegate, T.J., Angel, R. and Classen, H.L. 2003. Effect of dietary calcium, 25hydroxycholecalciferol, or bird strain on small intestinal phytase activity in broiler chickens. Poultry Sci., 82(7): 1140-1148.

Association of Official Analytical Chemists. 2012. Official Methods of Analysis of 
the Association of Official Analytical Chemists. 19th ed. AOAC Int., Arlington, VA.

Bachmann, H., Autzen, S., Frey, U., Wehr, U., Rambeck, W., McCormack, H. and Whitehead, C.C. 2013. The efficacy of a standardised product from dried leaves of Solanum glaucophyllum as source of 1, 25-dihydroxycholecalciferol for poultry. British Poultry Sci., 54(5): 642652.

Biehl, R.R. and Baker, D.H. 1997. Utilization of phytate and nonphytate phosphorus in chicks as affected by source and amount of vitamin D3. J. Animal Sci., 75: 2986-2993.

Cheng, Y.H., Goff, J.P., Sell, J.L., Dallorso, M.E., Gil, S., Pawlak, S.E. and Horst, R.L. 2004. Utilizing Solanum glaucophyllum alone or with phytase to improve phosphorus utilization in broilers. Poultry Sci., 83(3): 406-413.

Chennaiah, S., Qadri, S.S.Y.H., Reddy, C.V.K., Rao, S.R., Shyamsunder, G. and Raghuramulu, N. 2007. Incorporation of Cestrum diurnum leaf improves intestinal $\mathrm{Ca}$ transport in broilers. The J. Steroid Biochemistry and Molecular Biol., 103(3): 645-650.

DeLuca, H.F. 1974. vitamin D. The vitamin and hormone, federation proceedings. 33: 2211-2219.

Driver, A., Atencio, J.P., Pesti, G.M., Edwards, Jr. H.M. and Bakalli, R.I. 2006. The effect of maternal dietary vitamin D3 Supplementation on performance and tibial dyschondroplasia of broiler chicks. Poultry Sci., 85: 39-47.

Duncan, D.B. 1955. Multiple 'F' test, Biometrics, 1: 142.

Edwards, H.M. 2002. Studies on the efficacy of cholecalciferol and derivatives for stimulating phytate utilization in broilers. Poultry sci., 81(7): 1026-1031.

Fiske, C.H. and Subbarow, Y. 1925. The colorimetric determination of phosphorus. J. Biol. Chem., 66(2): 375400.

Garcia, A.F.Q.M., Murakami, A.E., do Amaral Duarte, C.R., Rojas, I.C.O., Picoli, K.P. and Puzotti, M.M. 2013. Use of Vitamin D3 and Its Metabolites in Broiler Chicken Feed on Performance, Bone Parameters and Meat Quality. Asian-Australasian $J$. Animal Sci., 26(3): 408-415.

Gitelman, H.J. 1967. An improved automated procedure for the determination of calcium in biological specimens. Anal. Biochem., 18(3): 521-531.

Gómez-Verduzco, G., Morales-López, R. and Avila-Gozàlez, E. 2013. Use of 25hydroxycholecalciferol in Diets of Broiler Chickens: Effects on Growth Performance, Immunity and Bone Calcification. The J. Poultry Sci., 50(1): 60-64.

Goodgame, S.D., Mussini, F.J., Lu, C., Bradley, C.D., Watkins, S.E. and Waldroup, P.W. 2011. Evaluation of a Fermentation Source of 25hydroxycholecalciferol in Broiler Diets1. Int. J. Poultry Sci., 10(4): 295299.

Hardy, M. and Edwards, J. 1993. Dietary 1, 25-Dihydroxycholecalciferol

Supplementation Increases Natural Phytate Phosphorus Utilization in Chickens. J. Nutri., 123: 567-577.

Knowles, T.G., Kestin, S.C., Haslam, S.M., Brown, S.N., Green, L.E., Butterworth, A., Butterworth, A., Pope, S.J., Pfeiffer, D. and Nicol, C.J. 2008. Leg disorders in broiler chickens: prevalence, risk factors and prevention. PLoS One, 3(2): e1545.

Landy, N., Toghyani, M., Researchers, Y., Club, E. and Branch, K. 2014. Evaluation the Effects of Dietary Cholecalciferol Substitution with 1alpha-Hydroxycholecalciferol on 
Performance and Tibia Parameters in Broiler Chickens. Int. J. Poultry Sci., 13(9): 515-517.

Michalczuk, M., Pietrzak, D., Niemiec, J. and Mroczek, J. 2010. Effectiveness of vitamin D3 and calcidiol (25-OH-D3) application in feeding broiler chickensproduction performance and meat quality. Polish J. Food and Nutrition Sci., 60(2): 121-126.

NRC, National Research Council. 1994. Nutrient Requirements of Poultry. 9th rev. ed. Natl. Acad. Press, Washington, DC.

Papesova, L., Fucikova, A., Pipalova, M. and Tupy, P. 2008. The synergic effect of vitamin D3 and 25hydroxycholecalciferol/calcidiol in broiler diet. Scientia Agriculturae Bohemica (Czech Republic) 39: 273277.

Rama Rao, S., Raju, M.V.L.N., Panda, A.K., Sunder, G.S. and Sharma, R.P. 2006. Effect of high concentrations of cholecalciferol on growth, bone mineralization, and mineral retention in broiler chicks fed suboptimal concentrations of calcium and nonphytate phosphorus. The J. Appl. Poultry Res., 15(4): 493-501.

Rama Rao, S.V., Raju, M.V.L.N., Shyam Sunder, G., Panda, A.K. and Pavani, P. 2007a. Growth, Bone Mineralization and Mineral Excretion in Broiler Starter chicks Fed Varied Concentrations of Cholecalciferol. Asian Australasian J. Animal Sci., 2: 237-244.

Snedecor, G.W. and Cochran, W.G. 1994. Statistical methods, 8th ed., (Iowa State University Press, Ames, Iowa, USA).

Sun, Z.W., Yan, L., Zhao, J.P., Lin, H. and Guo, Y.M. 2013. Increasing dietary vitamin D3 improves the walking ability and welfare status of broiler chickens reared at high stocking densities. Poultry sci., 92(12): 30713079.

Yan, F. and Waldroup, P.W. 2006. Non phytate phosphorous requirement and phosphorous excretion of broiler chicks fed diets composed of normal or high available phosphate corn as influenced by phytase supplementation and vitamin D source. Int. J. Poultry Sci., 3: 219228.

\section{How to cite this article:}

Narwade Vishal Shesherao, D. Nagalakshmi, S.V. Rama Rao, N. Nalini Kumari, T. Raghunanadan and Sridhar, K. 2017. Effect of Supplementing Plant Derived 1, 25 Dihydroxy Cholecalciferol on Performance and Bone Mineralization in Broiler Chicken Fed Suboptimal Concentrations of Calcium and Non Phytate Phosphorus. Int.J.Curr.Microbiol.App.Sci. 6(7): 1634-1641. doi: https://doi.org/10.20546/ijcmas.2017.607.197 